\title{
34 \\ The Bolsheviks in 1919: Notebook Entries
}

\section{Lenin}

Genial. Leaned elbow on tribune, crossed legs. Hands in pockets. Chuckled while speaking sometimes. Joked. Gestures - more frequently than ever [Reed here sketched two hands, palms extended, with the third and fourth fingers curled into palm] free hand in pocket. One pinched ordinary sack suit[,] collar[,] black four-in-hand [necktie]. Stout, broad, short [word indecipherable].

When you go to see him he hitches up his chair until his knees touch yours and looks through you with those terrible eyes[.] Not nervous. Swift but perfect master of self. Gives one impression of being intense[ly] interested.

Trotsky now filled out, surer of self, not impatient any more. Calmer, warmed, more genial also. A man. During defense of Petrograd went in front line personally \& stopped retreat.

Kamenev also plumper. Looks like cocker spaniel. Krestinsky - round-cheeked, thick glasses, Finance Commissar high in Party and close to Lenin. Mustache \& imperial.

Lunacharsky - thin nervous, delicate

John Reed Papers, Houghton Library, Harvard University 